\title{
Geoelectric Assessment of Groundwater Potential in Supare Akoko, Southwestern, Nigeria
}

\author{
Toluwaleke Ajayi ${ }^{1 *}$, Bola Awotuyi ${ }^{2}$, Rereloluwa Bello ${ }^{1}$ \\ ${ }^{1}$ Department of Earth Sciences, Crawford University, Igbesa, Ogun State, Nigeria \\ ${ }^{2}$ Department of Earth Science, Adekunle Ajasin University, Ondo State, Nigeria
}

Corresponding Author Email: ajayitoluwaleke@gmail.com

https://doi.org/10.18280/eesrj.060202

Received: 2 March 2019

Accepted: 29 May 2019

\section{Keywords:}

groundwater potential, geoelectric, vertical electrical sounding, overburden, basement

\begin{abstract}
Data from Geo-electrical survey using VES (vertical electrical sounding) measurements has been carried out in order to demarcate groundwater zones in Supare Akoko, Southwestern, Nigeria. Presently, the major source of drinking water supply in this area is via shallow hand dug wells and few borehole constructions provided by the government. In order to improve the standard of living of the community and ease the problem of water scarcity in the area, this study was initiated to delineate the groundwater potentials. Twenty (VES) was carried out with ABEM SAS-1000 Terrameter using the Schlumberger electrode array and the result shows three geoelectric layers within the study area. These subsurface layers include weathered layer, the topsoil, partially weathered/ fractured basement and fresh basement. Weathered zones, Valley fills/basement depressions, and fractured zones were the feasible groundwater pockets that were delineated in the study area. A series of bedrock ridges and depressions were delineated within the surveyed area. The isopach map revealed relatively high overburden thicknesses $(25 \mathrm{~m})$ within the depressions. The bedrock depressions were observed to be variably fractured. The main aquifer unit constitutes a relatively low resistivity weathered basement. Generally, the groundwater potential was zoned into low, medium and high. The VES station mapped as medium and high groundwater potential zones are viable for groundwater development within the study area. This study has proved to be quite successful for mapping fractures, outrocks types and structural formation which cannot be observed at the surface.
\end{abstract}

\section{INTRODUCTION}

In recent time, the people of Supare Akoko community have witnessed an exponential population increase. Students, civil workers and artisans/local traders were the main inhabitants that migrated to earn livings within the area coupled with the relocation of a state university to Akungba Akoko few years ago. The inhabitants depend majorly on water from hand-dug wells/shallow wells and surface water which runs out during the dry season. During this dry season, consumption of potable water is in limited amount, with most consumption sourced from water vendors and few boreholes sunk by some individuals and state government. These provisions are confirmed to be grossly inadequate as further efforts by state government and environmental agencies are not meeting proper expectations, as two out of every four boreholes sunk for water consumption usually fail once completed. Presently, the major source of drinking water supply in this area is via shallow hand dug wells and few borehole constructions provided by the government. The overall yields are somewhat variable considering the fact that the expected outcome is considered not enough for the entire populace. In order to improve the living standard of the community and ease the problem of water scarcity in the area, this study was initiated to delineate the Geological subsurface sequences and their groundwater potentials/ hydrogeological characteristics in the light of the notably sustainable groundwater potential yield of typical basement complex terrains.

Generally, under the influence of gravity in rock cavities, surface water accumulates after precipitation as a vast groundwater reservoir supplying boreholes, wells, flowing streams and springs. In a typical Basement Complex terrain, groundwater reservoir is usually contained within the weathered or faulted/jointed zones within the bedrock. These geological features leads to decrease in electrical resistivity at depth, hence increasing the permeability and porosity of such units to enable accumulation of groundwater, discharge and exploitation. This constitutes the basis of choosing electrical resistivity imaging survey in this study. The use of geophysical techniques for both water quality evaluations and groundwater resource mapping has increased dramatically over the years [1]. The vertical Electrical Sounding (VES) has proved very popular with groundwater evaluation studies because it investigates subsurface geological structures, thereby delineating contaminated subsurface zone. The Electrical resistivity imaging survey is more superior to all other electrical resistivity survey techniques particularly when dealing with groundwater evaluation in typical basement complex areas. The method is useful in imaging of the basement subsurface configuration over a long stretch of geological unit and where basement depressions are referred to as water collecting zone within the basement.

\section{SITE DESCRIPTION}

The study area is located in Supare-Akoko, Ondo State, South western, Nigeria (Figure 1). It is confined within 
latitudes 7.453670 and 7.457990 and longitudes 5.687320 and 5,695160 . The study area covers an area extent of about 1.5 $\mathrm{km}$ sq. The study area is accessible through secondary roads from Akungba-Akoko in the Northern part and Owo in the Southern part. The study area shows an undulating topography, it is fairly well drained with rivers which are seasonal and which form minor tributaries of the main rivers. The study area is characterized by dendritic drainage pattern. The areas are also heavily disserted by rivers which takes their resources from the hills. The river and stream channel in the area also display dendritic pattern (Figure 2). The study area falls under an unconventional climate region called sub-equatorial south. It has characteristically two climate seasons, which are the dry and wet seasons. Both wet and dry seasons with a mean annual rainfall of $1500 \mathrm{~mm}$ and average temperature of $27{ }^{\circ} \mathrm{C}$ also characterize the study area [2]. The wet season is characterized by heavy rainfall, which starts in March and ends in August, while the dry seasons starts in September and ends in February, although minor rainfall is usually experienced in March and October. The mean annual relative humility is above $80 \%$ while the mean annual rainfall is $150 \mathrm{~cm}$. The study area is also characterized by thick and light vegetation sharing boundary with rainforest and guinea savannah. Although, this area is typically basement complex, but the soil that eventually serve as support for the forest must have resulted from the weathering of the basement rocks and hill are present in the area. Figure 3 shows the base map of the study area.

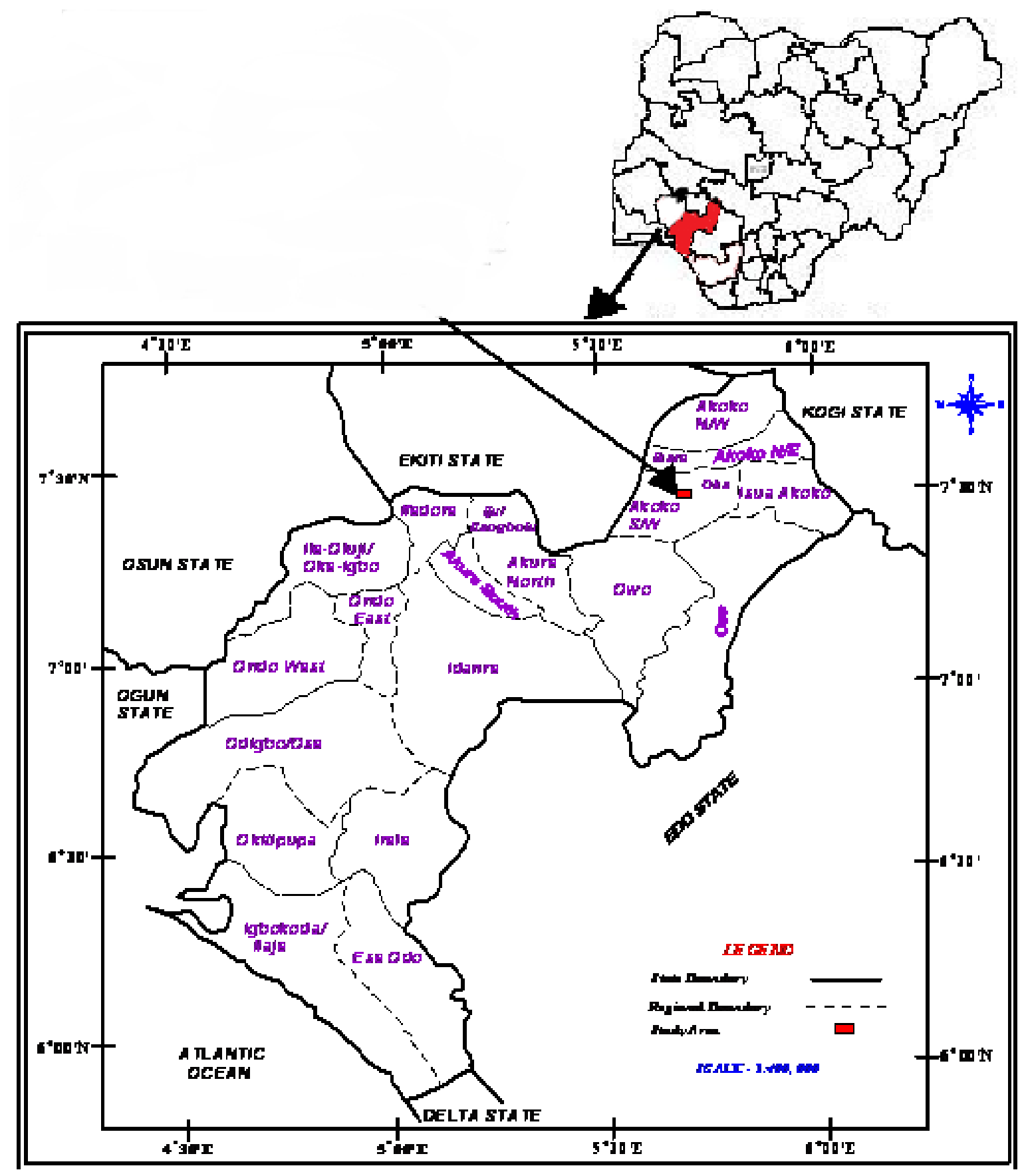

Figure 1. Map of Ondo State showing the study area and the layout [3] 


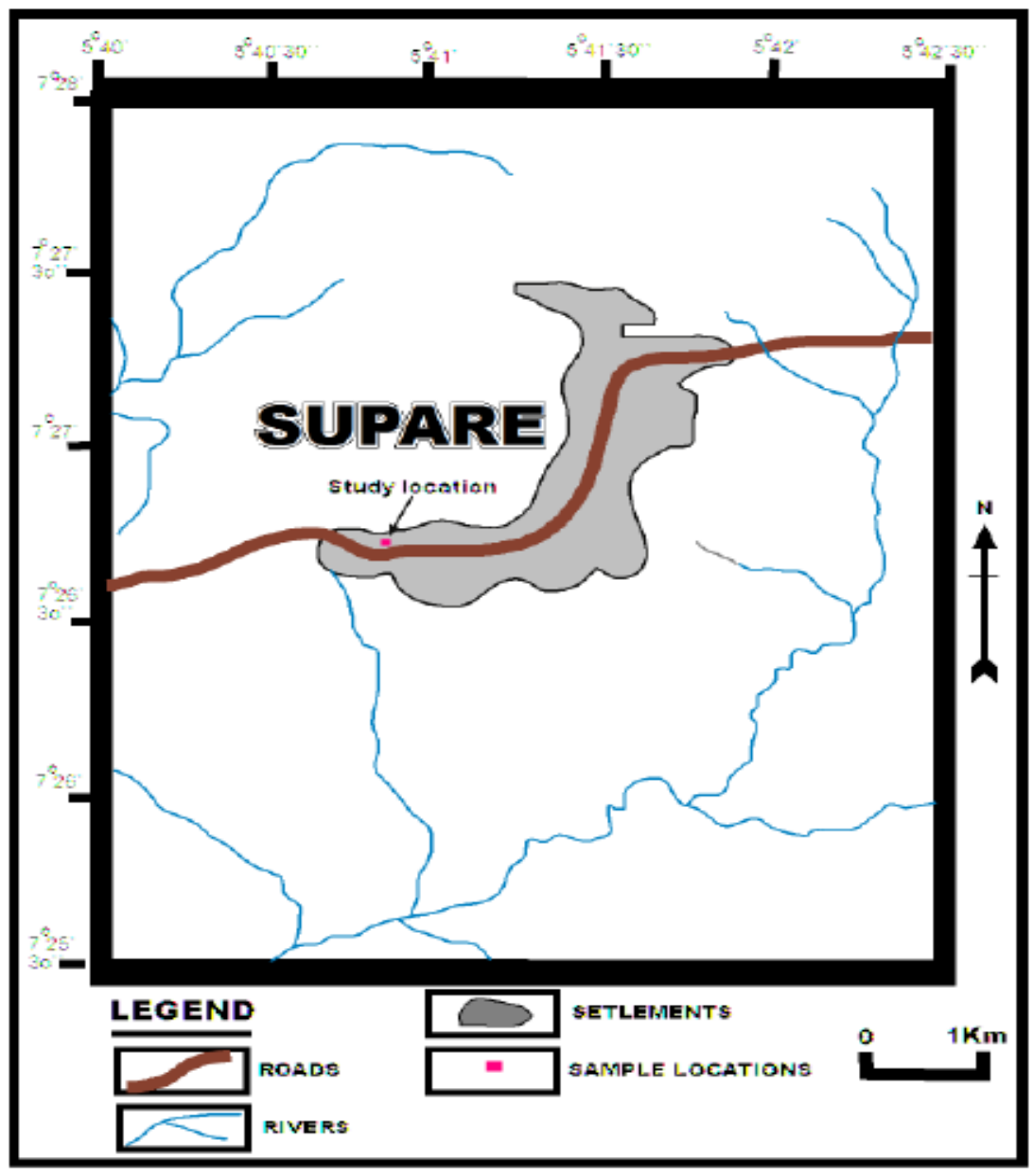

Figure 2. Drainage pattern of the area [3]

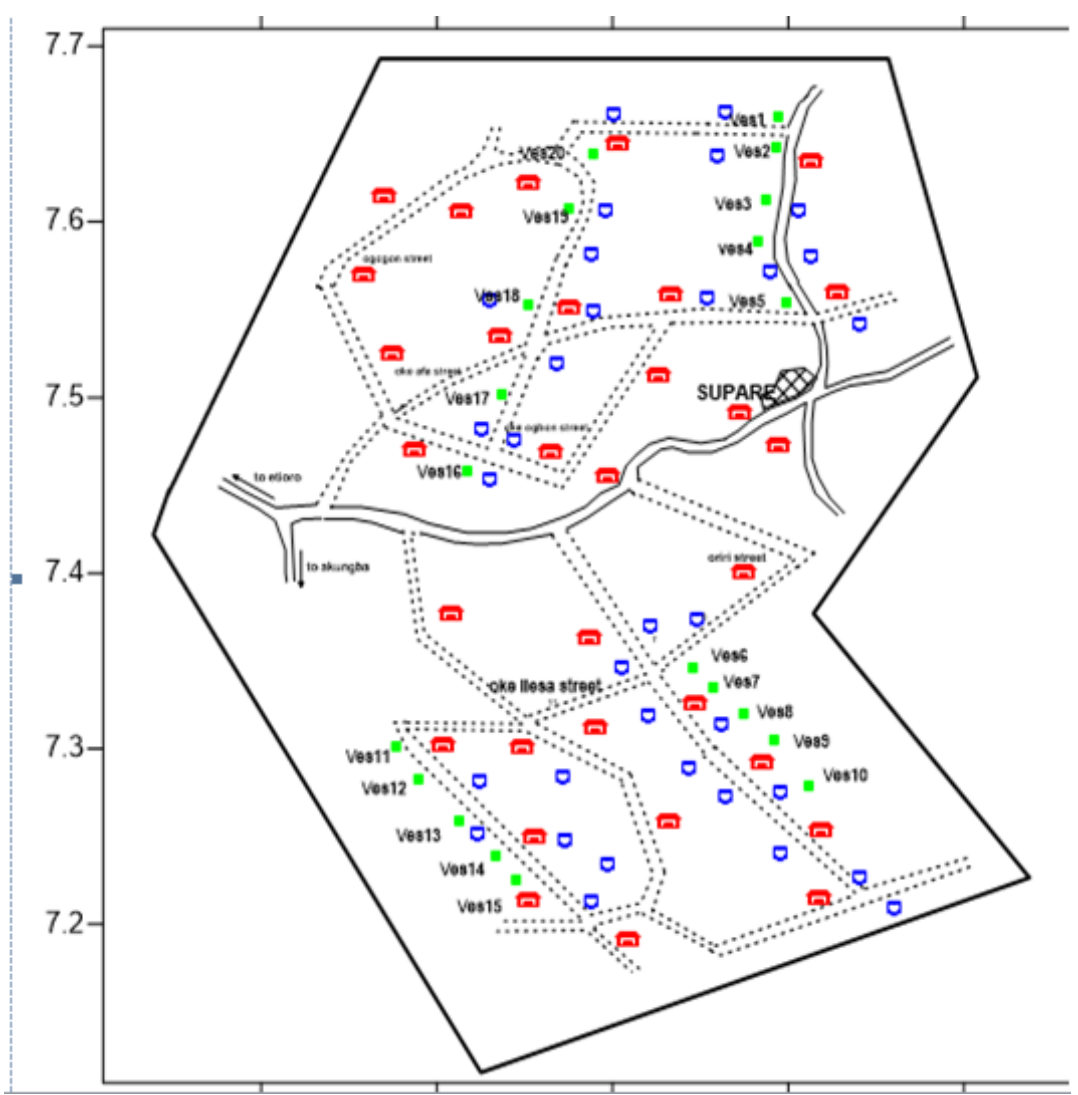

Figure 3. Base map of the study area 


\section{GEOLOGICAL SETTING}

Supare Akoko lies in the Basement Complex of Nigeria and the area is also underlained by the Precambrian Basement rocks of southwest Nigeria [3]. The study area falls within the basement area of Ondo State as shown in Figure 4. Granite with minor occurrence of migmatites gneiss is the dominant rock type in the area. The Granite rock is a fine to medium to course grained, strongly foliated and is extremely dark in color; the rock is used for ornamentation and construction by a wellknown tiling company known as Crushed Rock Industry Nig. Ltd. Also, beneath the sites, is a presence of fresh bedrock, a boulder or a partially weathered metamorphic or igneous rock in the area. Figure 5 shows the topographical map of the area.

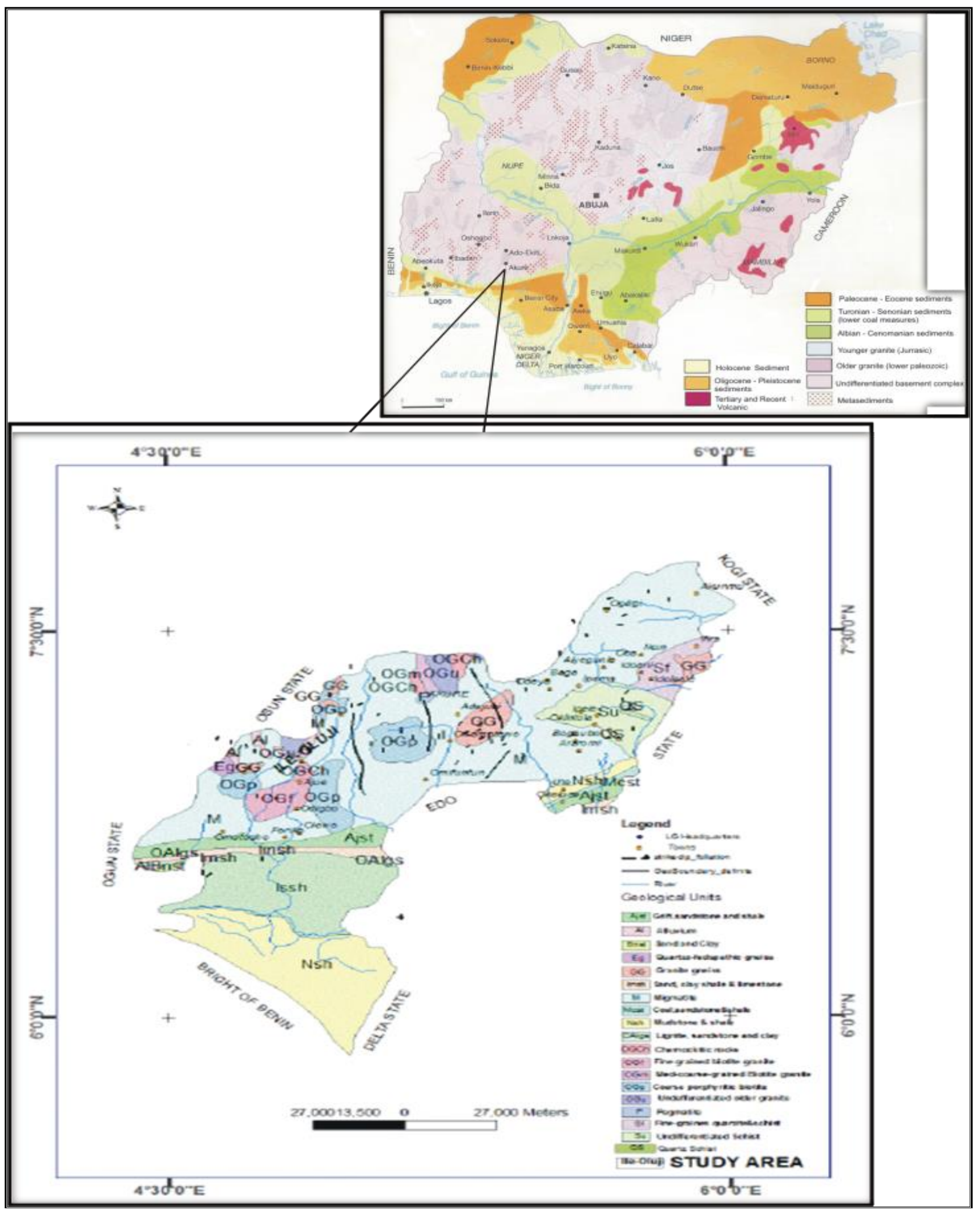

Figure 4. Geological map of Ondo State showing study area (modified after GSN) 


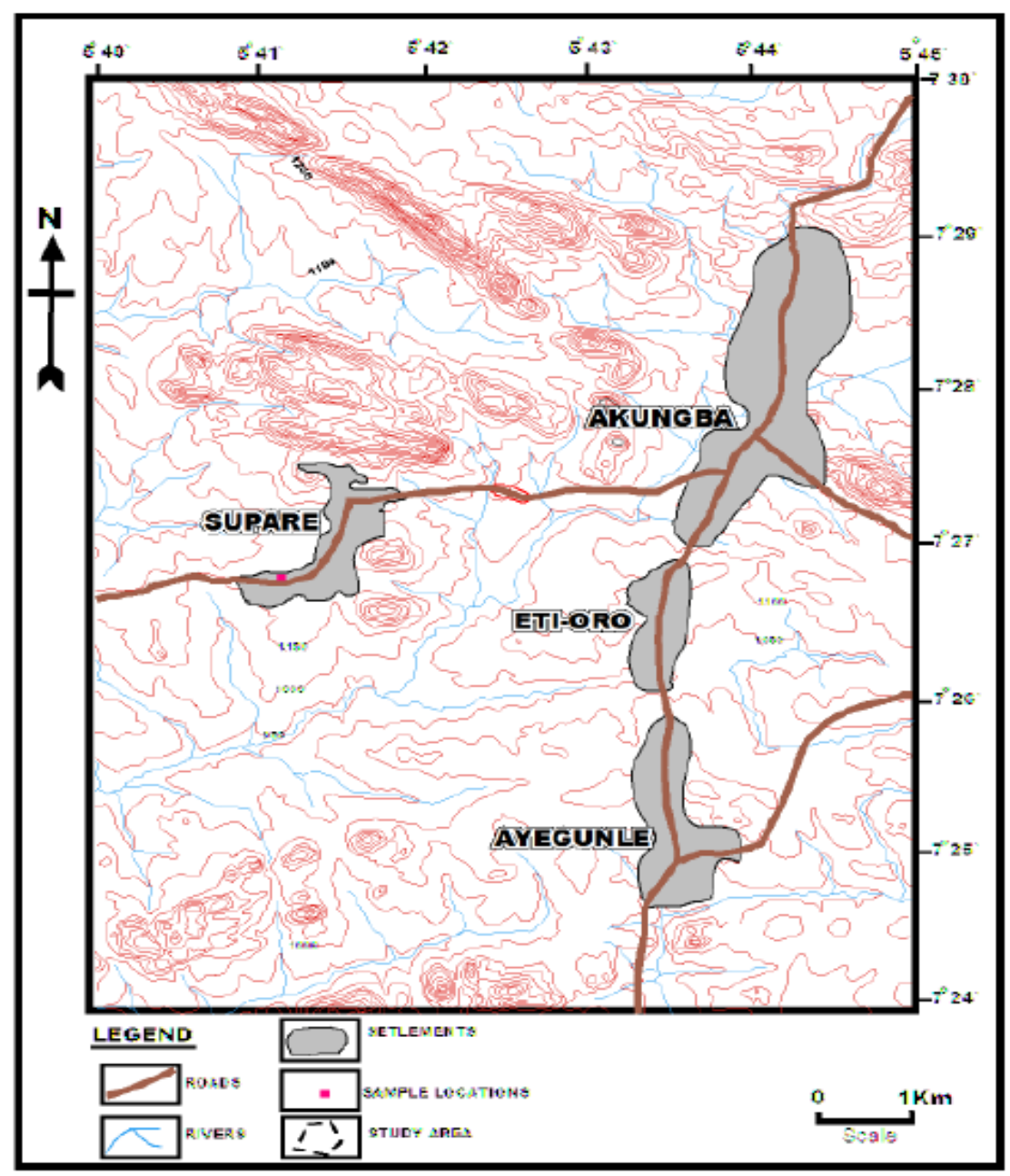

Figure 5. Topographic map of the study area [3]

\section{MATERIAL AND METHODS}

The geophysical technique used for this study is the Vertical Electrical Sounding (VES) techniques and Electrical resistivity method. The ABEM SAS-1000 Terrameter was the Geophysical instrument used along with hammer for driving the electrodes into the ground, four metallic electrodes, and four reels of connecting electrical cables (two red coloured cables for potential electrodes while the two black coloured cables are for current electrodes), cutlass for cutting traverses, a measuring tape and clips. GPS (Global Positioning System) was used to determine the coordinate of the VES points. During geophysical data acquisition, calibrated rope and data sheet were used for recording the field survey data. The resistivity meter contains receiver unit, through which the resultant potential difference is recorded and a transmitter unit, through which current enters the ground. The Schlumberger survey array was used for the study and the electrode spread of $\mathrm{AB} / 2$ was varied from 1 to a maximum of $65 \mathrm{~m}$. The expected depth of investigation was $(\mathrm{D})=0.125 \mathrm{~L}$, where $\mathrm{L}=$ $\mathrm{AB} / 2$, and $\mathrm{AB}$ is the current electrode separation. Data were presented as sounding curves which is obtained by plotting apparent resistivity against $\mathrm{AB} / 2$ or half the spread length on a bi-log paper. ABEM SAS-1000 Terrameter was used to record the ground resistance. The resulting electrical resistances obtained were further multiplied by $(\mathrm{k})$ which is the geometric factor for each electrode separation in order to obtain the apparent resistivity ( $\rho=k R)$ in ohm-meter. The resulting models obtained from the calculations stated above were used for computer iteration in order to obtain the thickness and true resistivity of the layers. Comparism was made between the computer-generated curves and the corresponding field curves by using a computer program "Resist" version 1.0. The software was further used for both modeling and computer iteration.

\section{RESULTS AND DISCUSSION}

\subsection{Sounding curves}

Seven curve types were identified in the study area, these are H, Q, HA, K, QH, KH and A (Figure 6). Table 2 shows the occurrence of these curve types where type curve $\mathrm{H}$ has the highest percentage (35\%) of occurrence, $\mathrm{K}$ curve type has $10 \%, \mathrm{QH}$ and HA curve types have $(20 \%)$, occurrence while $\mathrm{Q}$ and A curve type have $5 \%$. Some of the typical curve types are as shown in Figures 7 to 9. It is often possible to make qualitative hydrogeologic deductions from curve type [4]. The summary of VES interpretation result is shown in Table 1. The $\mathrm{KH}$ curve type thus suggest subsurface geoelectric configuration that favors groundwater potential. 
Table 1. Table showing summary of VES interpretation result

\begin{tabular}{|c|c|c|c|c|c|c|c|c|}
\hline VES & $\boldsymbol{\rho ~ 1}$ & $\mathbf{\rho 2}$ & $\mathbf{\rho 3}$ & $\mathbf{\rho 4}$ & $\mathbf{h 1}$ & $\mathbf{h} \mathbf{2}$ & $\mathbf{h 3}$ & curve \\
\hline 1 & 903 & 350.1 & 716.4 & & 1.9 & 13.1 & & H \\
\hline 2 & 700.4 & 3888.8 & 375.1 & & 1.1 & 6 & & Q \\
\hline 3 & 248.9 & 154.4 & 914 & 1566.8 & 2.3 & 6.7 & 16.5 & HA \\
\hline 4 & 293.6 & 382.5 & 76.4 & & 1 & 7.5 & & K \\
\hline 5 & 345.3 & 293.1 & 94 & 213.9 & 2.11 & 4 & 10.5 & QH \\
\hline 6 & 448 & 196.6 & 649.6 & & 1.5 & 6.9 & & H \\
\hline 7 & 374.2 & 224.2 & 989.2 & 1710.5 & 1 & 3.4 & 10.9 & HA \\
\hline 8 & 861.2 & 328.3 & 238 & 1402.9 & 2.5 & 16.2 & 17 & QH \\
\hline 9 & 883.4 & 97.2 & 305.1 & 4762.9 & 2.9 & 6.8 & 7.7 & HA \\
\hline 10 & 275 & 154 & 255.1 & 2073.7 & 1.9 & 7.8 & 22.8 & HA \\
\hline 11 & 288.9 & 71.4 & 2570.9 & & 3.1 & 12.6 & & H \\
\hline 12 & 553.1 & 858.4 & 676.5 & & 4.1 & 4.6 & & K \\
\hline 13 & 462.2 & 184.9 & 123.3 & 2740.6 & 2.7 & 14.6 & 17 & QH \\
\hline 14 & 261.1 & 121.9 & 114.4 & 1288.7 & 1.3 & 13.1 & 16 & QH \\
\hline 15 & 103.3 & 26.4 & 26908.3 & & 2.7 & 8.3 & & H \\
\hline 16 & 181.7 & 97.2 & 832.9 & & 2.7 & 6.6 & & H \\
\hline 17 & 1566.5 & 106.8 & 4087.4 & & 1.8 & 15.9 & & H \\
\hline 18 & 419 & 680.2 & 91.7 & 12207.6 & 2.4 & 3.5 & 11.9 & KH \\
\hline 19 & 302.7 & 360.4 & 1259.0 & & 1.2 & 15.3 & & A \\
\hline 20 & 268.2 & 86.4 & 691.5 & & 3.7 & 7 & & H \\
\hline
\end{tabular}

Table 2. Curve type distribution in the study area

\begin{tabular}{|c|c|c|}
\hline Curve & Frequency & Percentage \\
\hline $\mathrm{H}$ & 7 & $35 \%$ \\
\hline $\mathrm{Q}$ & 1 & $5 \%$ \\
\hline $\mathrm{HA}$ & 4 & $20 \%$ \\
\hline $\mathrm{K}$ & 2 & $10 \%$ \\
\hline $\mathrm{QH}$ & 4 & $20 \%$ \\
\hline $\mathrm{KH}$ & 1 & $5 \%$ \\
\hline $\mathrm{A}$ & 1 & $5 \%$ \\
\hline
\end{tabular}

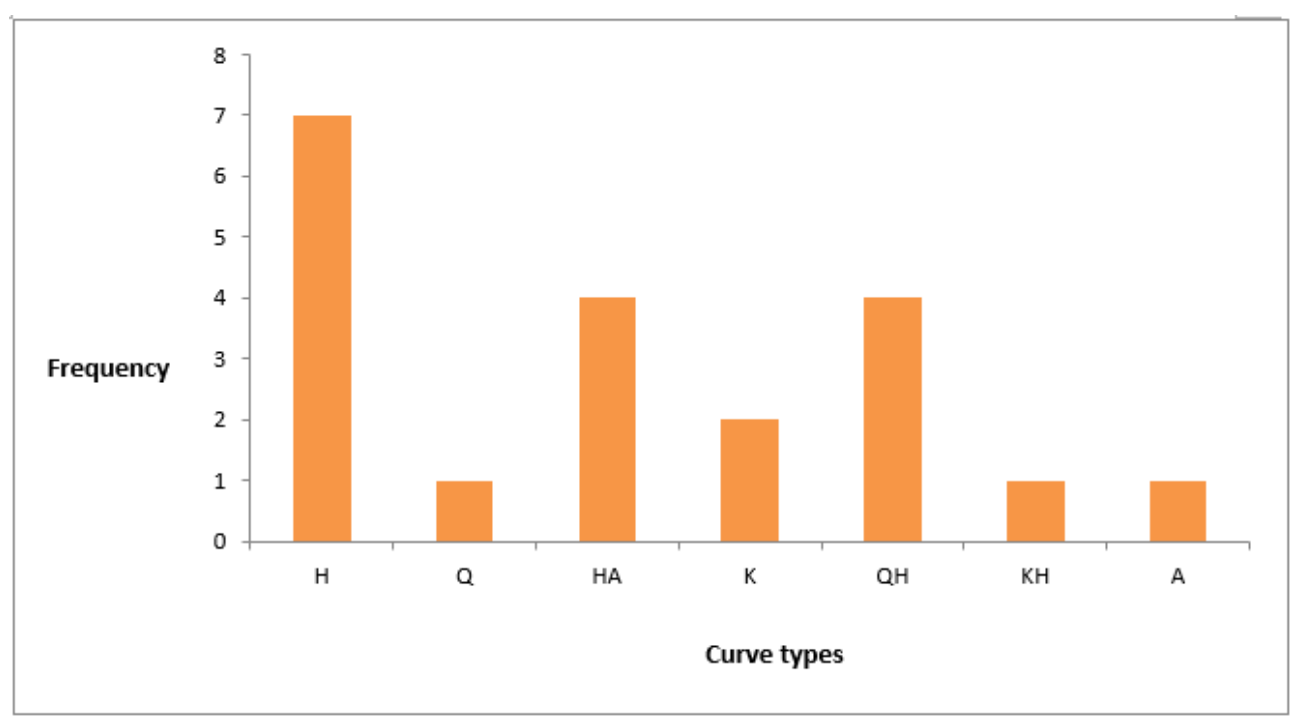

Figure 6. Frequency distribution of the observed curve types at Supare Akoko 


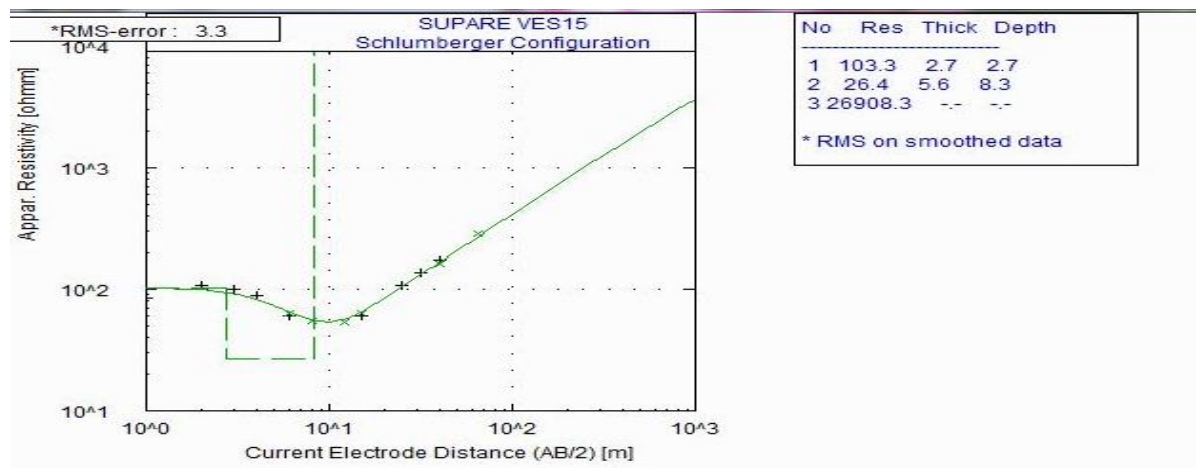

Figure 7. Typical H curve type
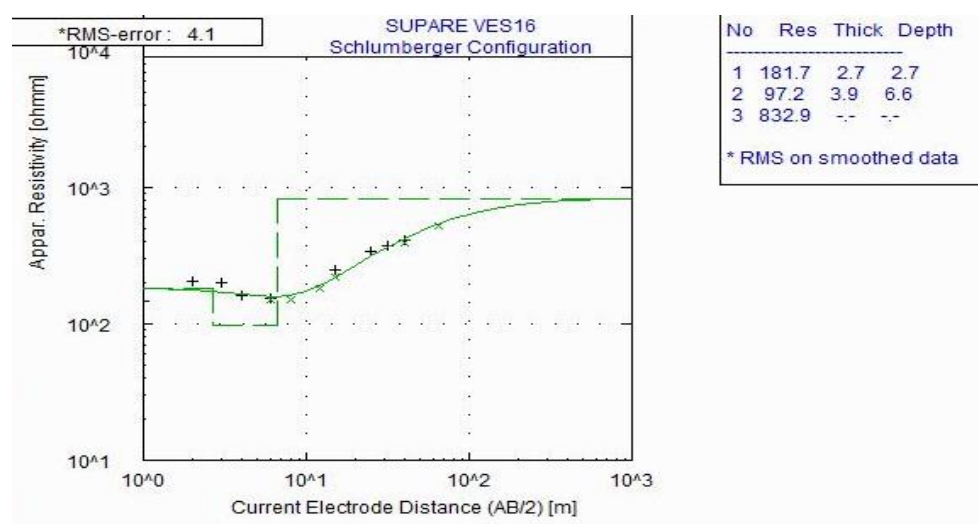

Figure 8. Typical H curve type
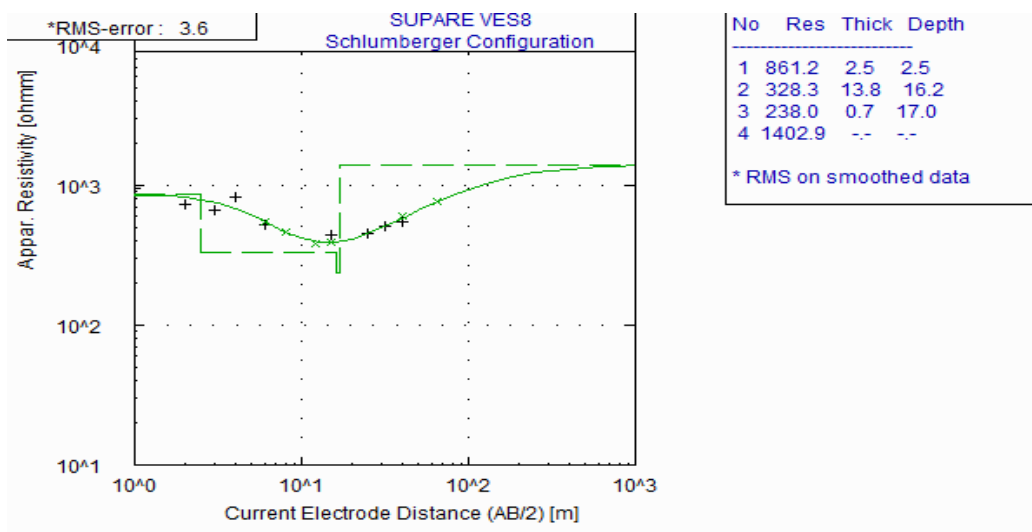

Figure 9. Typical QH curve type

\subsection{Geoelectric sections}

Figure 10 to 13 shows four geoelectric sections along in the $\mathrm{N}-\mathrm{S}, \mathrm{W}-\mathrm{E}$ direction. The geoelectric section shows the thickness values of layers and variation of resistivity within the depth penetrated in the study area at the indicated VES station. The geo-electric section across the stations shows the different subsurface layers and the depth at which they are encountered during the course of investigation in relation to layer resistivity. The geoelectric section revealed four (4) subsurface geologic layers. They are weathered layer, topsoil, fresh and fractured bedrock. The topsoil thickness is relatively thin along these profiles and ranges between 0.1 and $3.1 \mathrm{~m}$ while the resistivity values range between 293.6 and 903.4 ohm-m, which indicates that the main composition of the topsoil is sandy clay, lateritic clay, and clayey sand. The resistivity values also range from 154.4 to $388.8 \mathrm{ohm}-\mathrm{m}$, which indicated that the material composition is largely clayey sand, clay and sandy clay. The weathered layer thickness ranges from 1.9 to $11.2 \mathrm{~m}$ along the profiles (Figure 10). The fractured bedrock resistivity values range between 76.4 and $914 \mathrm{ohm}-\mathrm{m}$ which indicates a high degree of fracture and water saturation. It is of in- finite thickness where it is the last observable layer and when it is underlain by the fresh basement the thickness is greater than $15 \mathrm{~m}$. The last layer is fresh bedrock with resistivity values that range between 346 
ohm-m and infinity (fresh basement). At most VES stations, it is infinitely resistive due to its crystalline nature. It was also observed that the Geoelectric section of VES 6-20 (Figures 11-
13) had similar trends in terms of resistivity range both topsoil and weathered layer and will not be repeated.

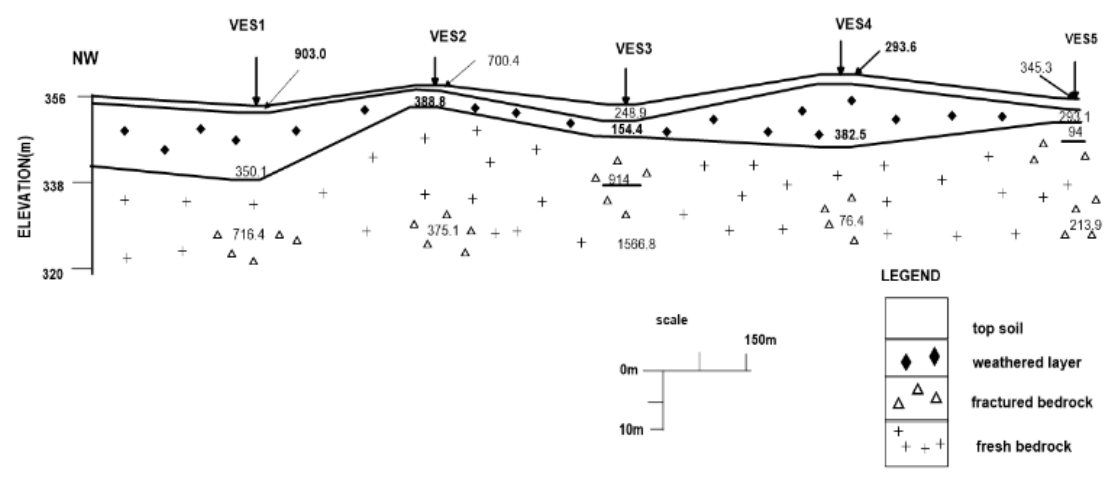

Figure 10. N-W Geoelectric section along VES 1,2,3,4 and 5 (resistivity in $\Omega \mathrm{m}$ )
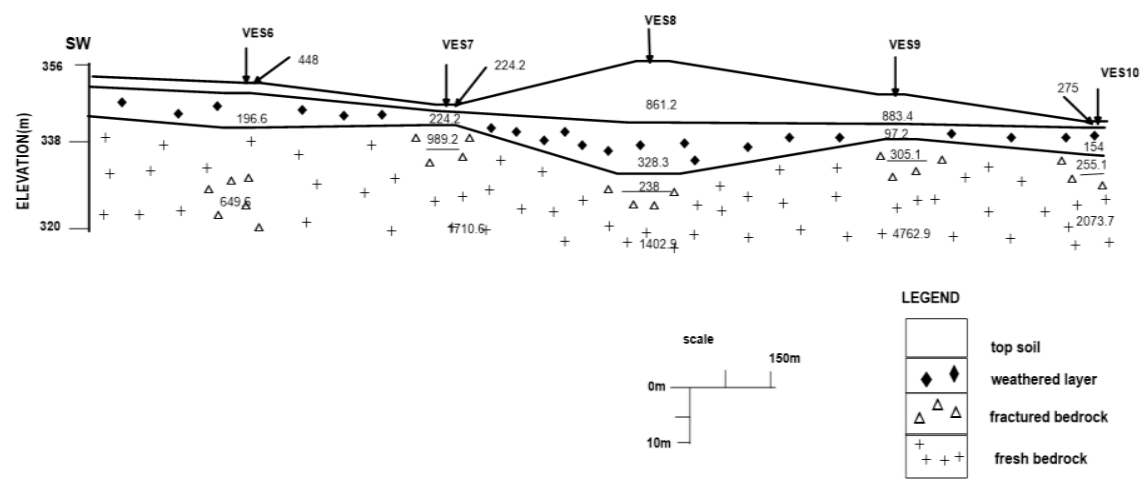

Figure 11. S-W Geoelectric section along VES 6,7,8,9 and 10 (resistivity in $\Omega \mathrm{m}$ )

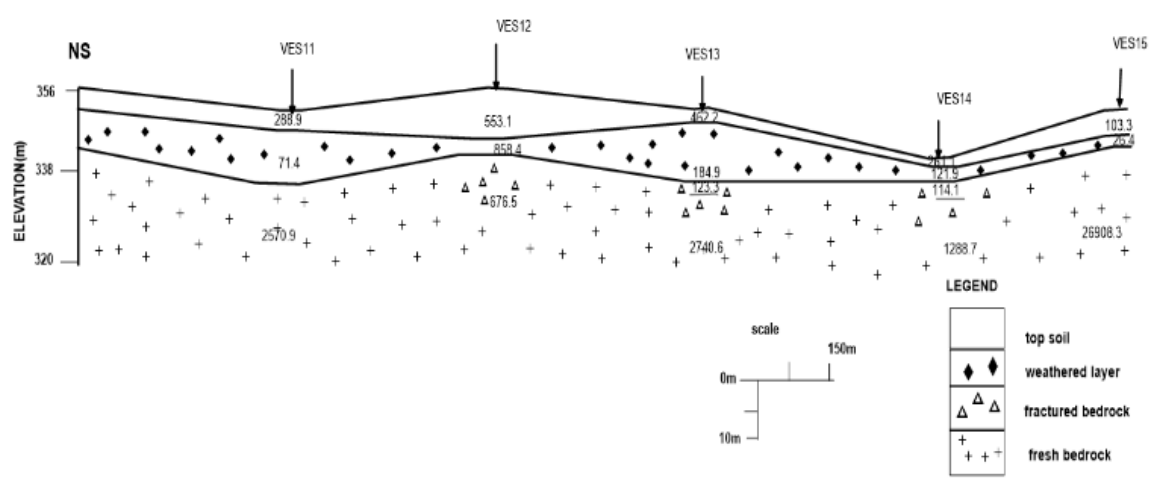

Figure 12. N-S Geoelectric section along VES 11,12,13,14 and 15 (resistivity in $\Omega \mathrm{m}$ )

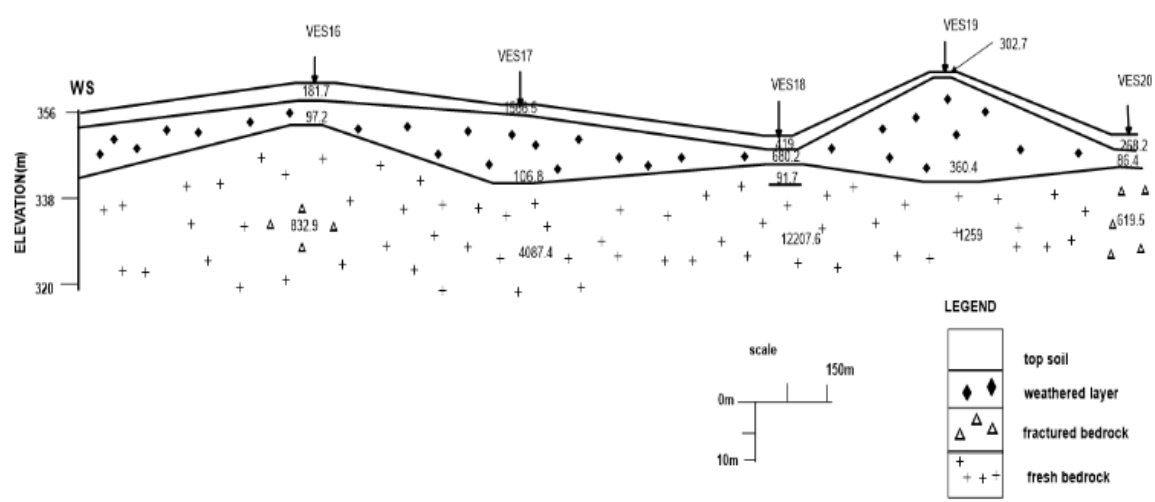

Figure 13. W-S Geoelectric section along VES 16,17,18,19 and 20 (resistivity in $\Omega \mathrm{m}$ ) 


\subsection{Isoresistivity map of topsoil}

Figure 14 shows the Isoresistivity map of the topsoil. The result shows that the resistivity values range from 100-1000 $\Omega \mathrm{m}$ but mostly less than $500 \Omega \mathrm{m}$. This shows the high heterogeneous variation in the composition of the topsoil from sandy clay, clay, laterite and clayey sand. This lithology has small hydrogeological significance because of its variable composition and also due to small thickness as shown in the geoelectric sections.

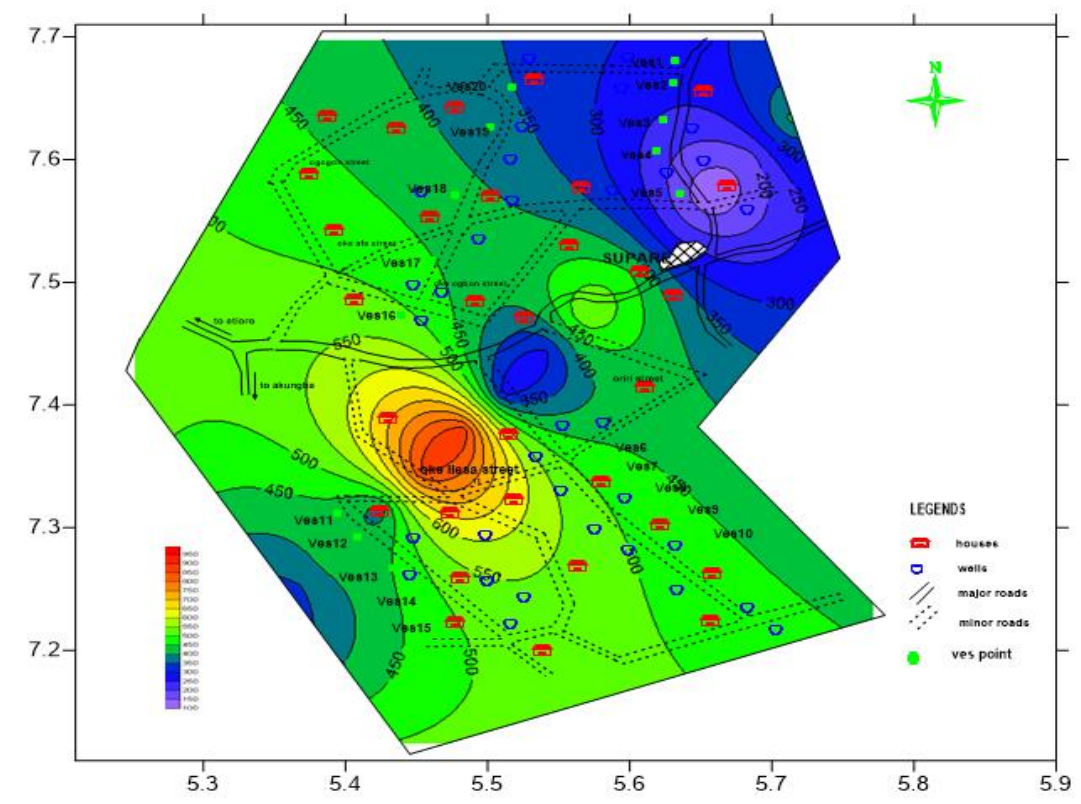

Figure 14. Isoresistivity map of the topsoil in Supare Akoko

\subsection{Isoresistivity map of weathered layer}

The resistivity values of the weathered layer ranges from 6.5 to $1250 \Omega$-m (Figure 15). This shows that the material composition is largely clay/clayey sand [4]. Varieties of texture of granites is the basement rocks of the study area ranging from coarse to fine grained materials. The fine grained type weathered into clayey residual soil, which has poor wateryielding aquifer unit wherever it forms underlying basement rock while the coarse grained type weathered into water bearing residuals soil with a good water yield strength. The map demarcated the low water bearing ones from high water bearing weathered basement zones which indicates the variations in the degree of saturation/weathering across the area. Low weathered basement resistivity zones characterized by low resistivity values are probably due to the fact that the weathered basement layer is saturated with water at the zones and also high weathered nature of the weathered basement layer which tends towards clay. The presence of substantial amount of clay and very thin nature of the weathered basement layer across the zones rendered the potentials for groundwater low. The zones underlain by less percentage of clay and thick overburden with appreciable degree of saturation as delineated on the map hold high groundwater potentials $[5,6]$.

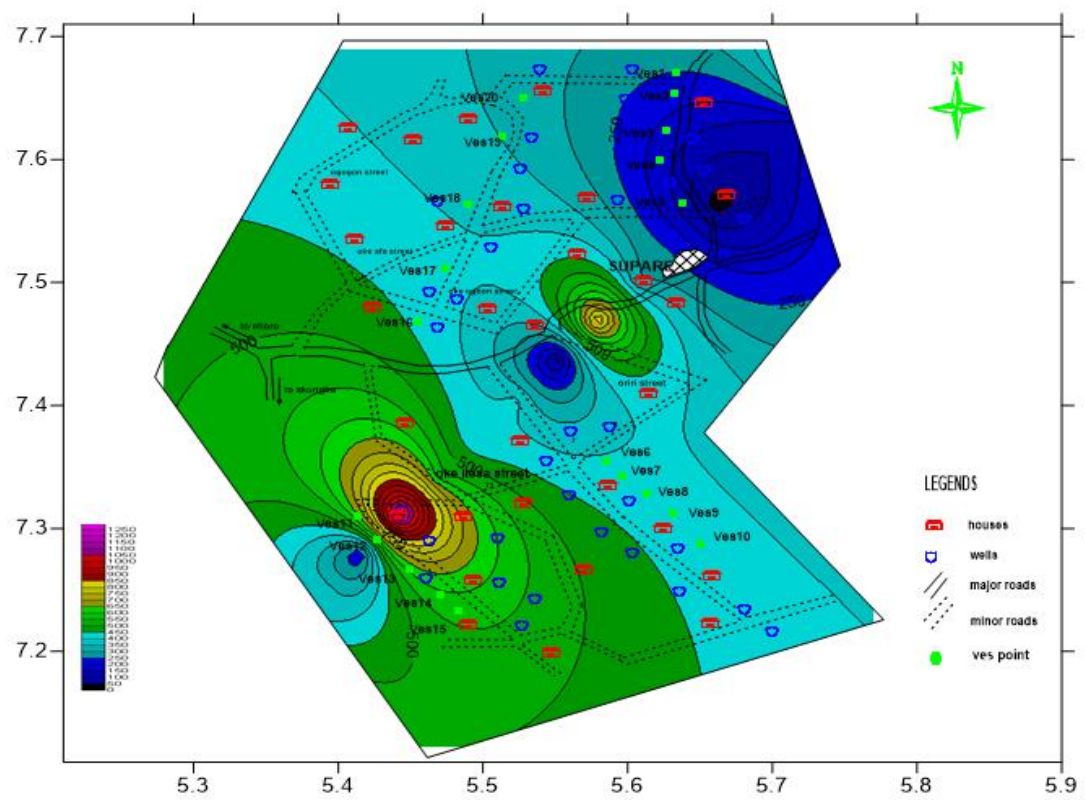

Figure 15. Isoresistivity map of the weathered layer in Supare Akoko 


\subsection{The weathered layer thickness}

The weathered basement thickness map (Figure 16) can be used to identify and analyze potential/promising aquifers. The map reveals the variation of the weathered basement layer across the area. The thickness of the layer ranges from 3 to 25 $\mathrm{m}$ with a mean of $14 \mathrm{~m}$. Since the weathered basement zone is believed to be the main aquifer, the zone offers a very strong appeal for groundwater potential development. The average weathered basement layer thickness of about $14 \mathrm{~m}$ recorded at some VES stations points (VES5, VES6, and VES7) delineates those zones of the study area as potential aquifers.

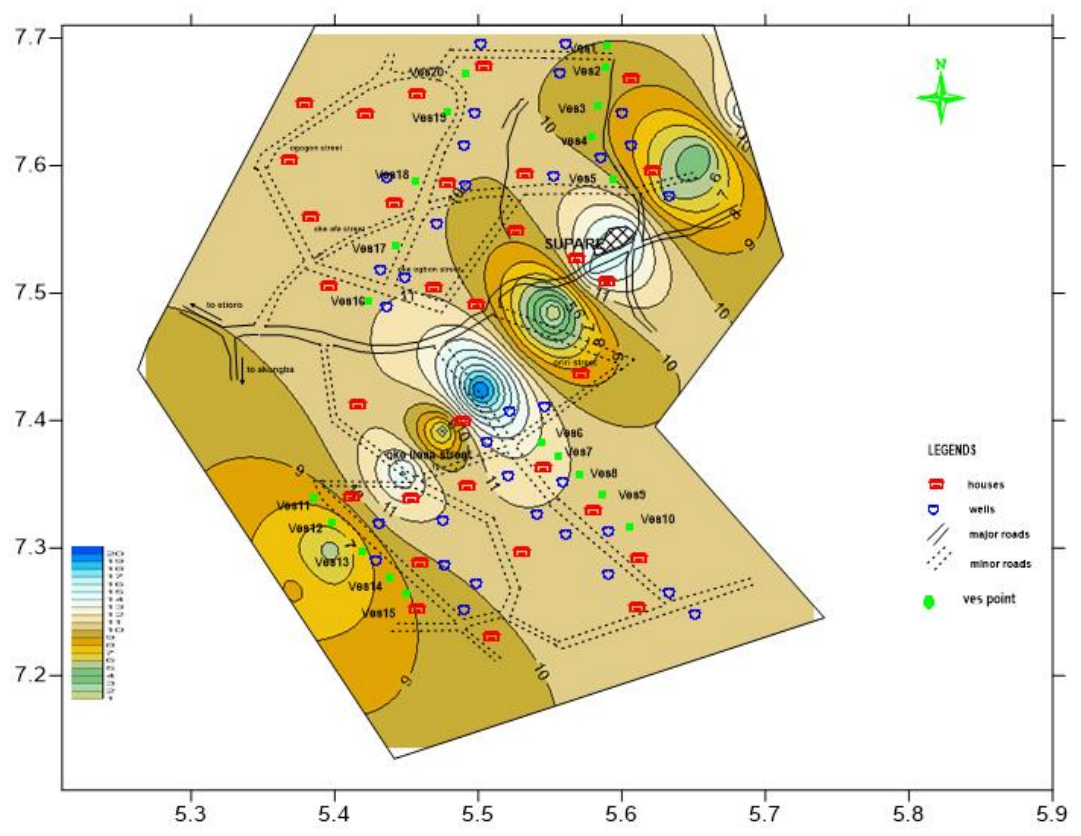

Figure 16. The weathered layer thickness map in Supare Akoko

\subsection{Overburden isopach map}

Figure 17 shows the isopach map of overburden of the study area with a contour interval of $1 \mathrm{~m}$. The map provides an overall view of the aquifer geometry in the study area. The overburden houses all materials above the presumably fresh bedrock. It is defined as the total depth from the surface to the top of bedrock at each of the VES station. It can be seen from the result that the depth - to - bedrock varies from 5 to $25 \mathrm{~m}$. The result is in agreement with [7] which predicted a range of 4.0 to $80 \mathrm{~m}$ as possible overburden thickness in a similar geological terrain of the basement complex area of Akure, Southwestern, Nigeria. It can be seen from the map that the bedrock is not a continuous and smooth, rather, it shows undulating configuration. The isopach map reveals zones of thin overburden less than $10 \mathrm{~m}$ and thick overburden greater than $13 \mathrm{~m}$. Studies in similar basement complex terrain $[1,8]$ also identified areas with thick overburden cover as potential groundwater zones. Consequently, areas with overburden thickness greater than $13 \mathrm{~m}$ are priority areas for groundwater development.

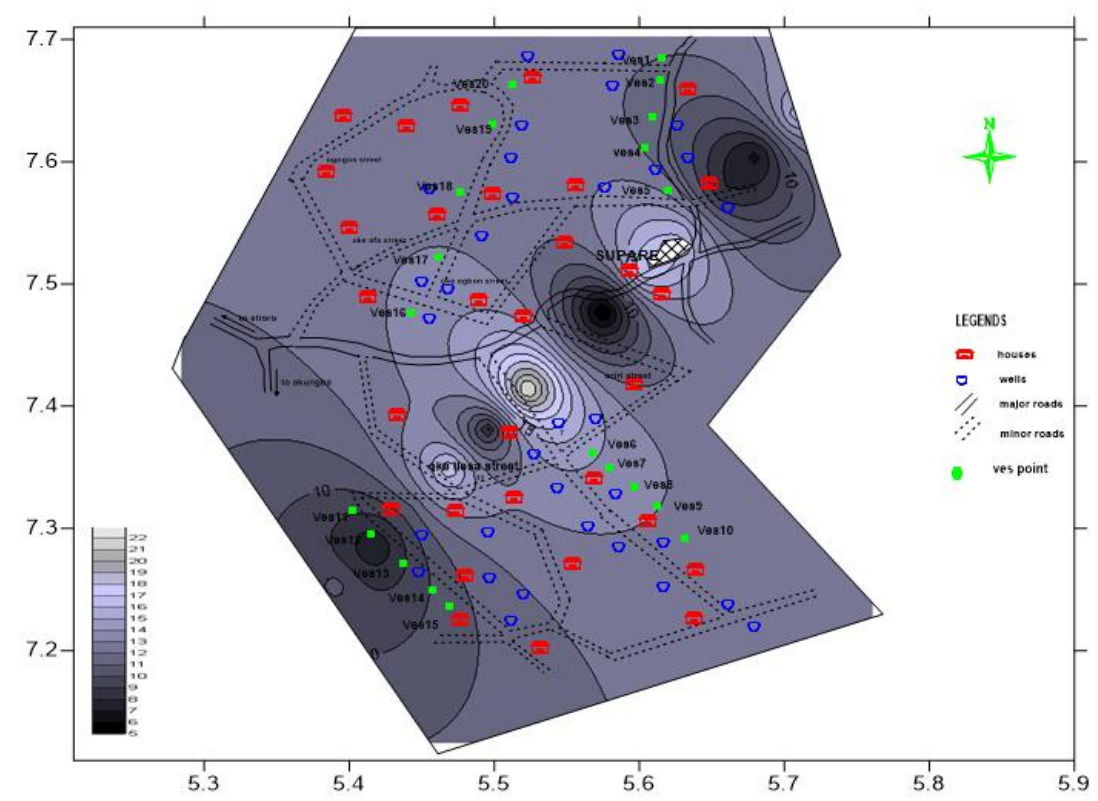

Figure 17. Isopach map of the overburden at Supare Akoko 


\subsection{The bedrock relief map of the study area}

The bedrock relief map (Figure 18) is a contoured map of the bedrock elevation beneath all the VES stations. The bedrock relief map reflects the bedrock disposition and topography. These elevations were obtained by removing the overburden thickness from the elevation of the surface of the
VES stations. The map delineates a series of bedrock depressions and ridges within the survey area. The depressions are characterized by thick overburden while bedrock ridges show thin overburden. The depression also shows low resistivity values. The bedrock depressions are basically used to diagnose groundwater collecting centres. They are therefore demarcated as priority areas for groundwater potential [9].

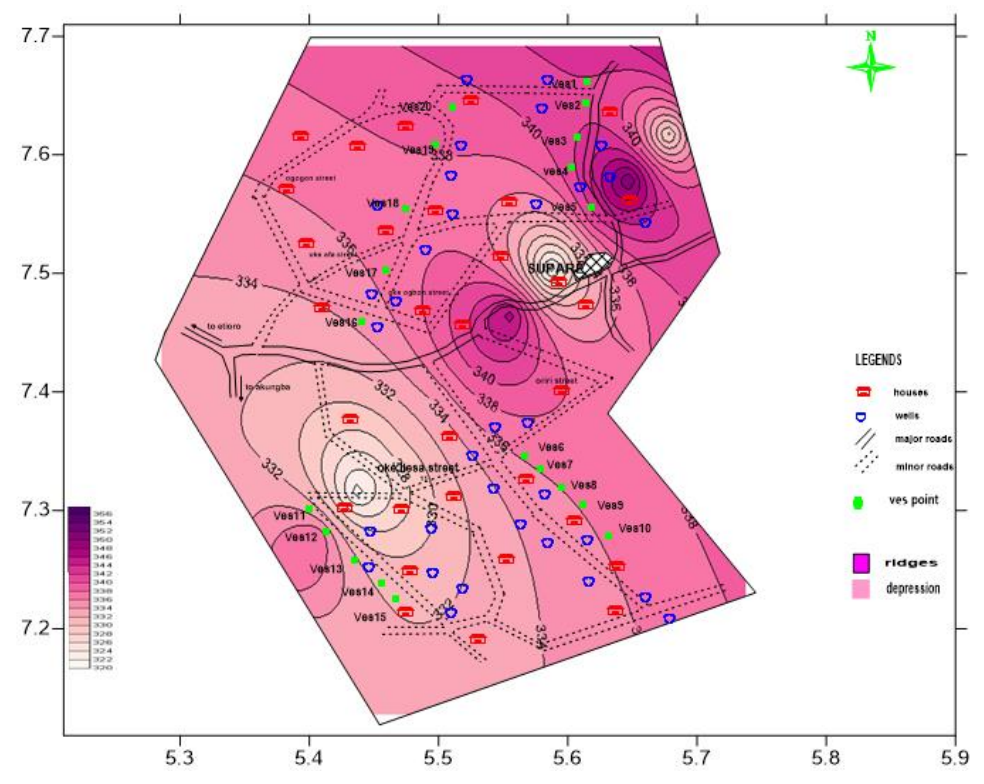

Figure 18. Bedrock relief map at Supare Akoko

\subsection{Groundwater evaluation}

In order to draw the final conclusion from the evaluated maps, groundwater potential map of the study area was produced. Figure 19 shows the groundwater potential map of the study area. The evaluation of the study area is based on the resistivity of the weathered layer and thickness of the overburden, since the important parameters in the groundwater potential evaluation of a basement complex terrain are nature of the weathered layer and its thickness $[8,10]$. The horizons is also referred to as a major water bearing zone most especially if significantly thick and the resistivity parameters reveals saturated conditions $[6,8]$. The groundwater potential of the study area was zoned into low, medium and high potentials. In this study, zones where the thickness of the overburden is greater than $13 \mathrm{~m}$ and of low clay content with average resistivity value between 200 - $400 \Omega \mathrm{m}$ are considered zones of high groundwater potential. Area where the aquifer thickness ranges 11-13 m with less clay composition are considered medium groundwater potential and the areas where the aquifer thickness is less than $11 \mathrm{~m}$ are considered to have a low groundwater potential.

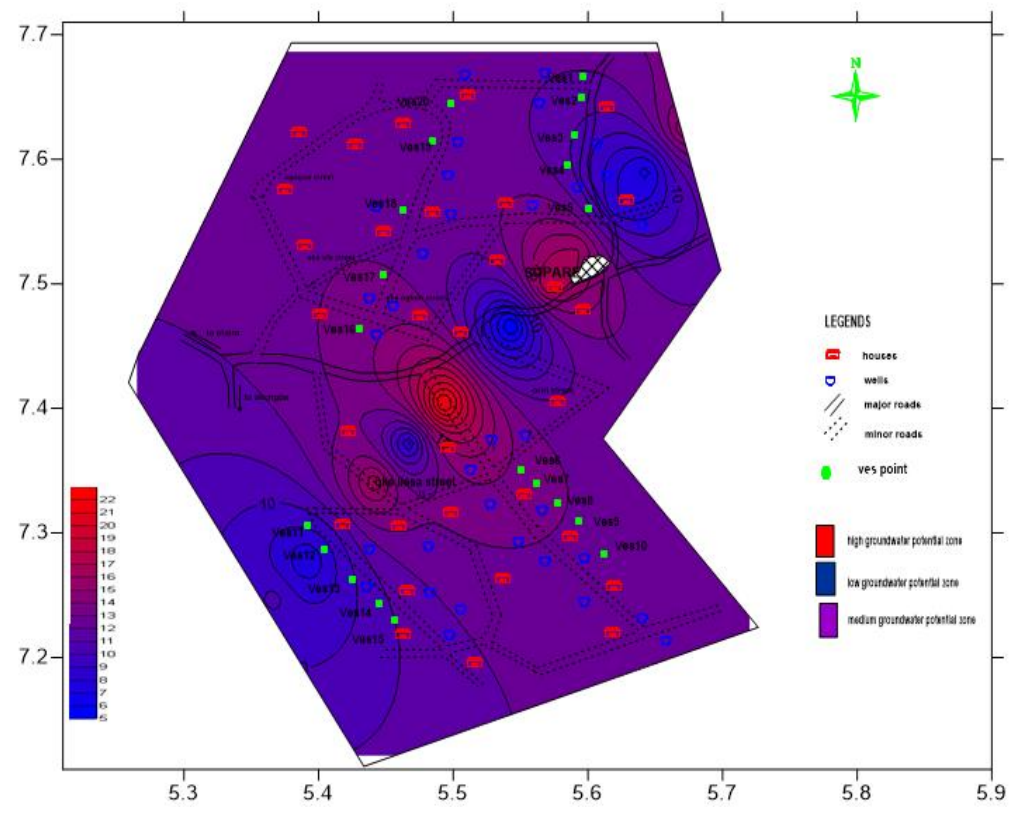

Figure 19. Groundwater potential map at Supare Akoko 


\section{CONCLUSIONS}

The study has been able to reveal the importance of electrical resistivity method in hydrogeologic characterization and groundwater development. This study has proved to be quite successful for mapping fractures, outrocks types and structural formation which cannot be observed at the surface. Geo-electrical analysis of data obtained from VES (vertical electrical sounding) measurements has been carried out to identify groundwater potential zones in Supare Akoko, Southwest, Nigeria. Groundwater pockets like fractured zones, valley fills/basement depressions and weathered zones were delineated in the study area. The bedrock relief maps demarcated depressions and bedrock ridges within the surveyed area. The isopach map of the overburden reveals high overburden thicknesses $(25 \mathrm{~m})$ within the depressions. The bedrock depressions are observed to be variably fractured. The low resistivity weathered basement constitutes the major aquifer unit. The area was zoned into low, high and medium groundwater potential. The VES station underlained by medium and high groundwater potential zones are viable for groundwater development within the area. Future groundwater development in the study area should be concentrated within the high/medium groundwater potential zones with good/moderate aquifer protective capacity.

\section{REFERENCES}

[1] Omosuyi, G.O., Ojo, J.S., Enikanselu, P.A. (2003). Geophysical investigation of groundwater around Obanla-Obakekere in Akure area within the basement complex of south-western Nigeria. Journal of Mining and Geology, 39(2): 109-116. https://doi.org/10.4314/jmg.v39i2.18799

[2] Jones, H.A., Hockey, R.D. (1964). The Geology of Part of Southwestern Nigeria. Geol. Surv. Nigeria, Bull, 31, pp. 101.

[3] Rahaman, M.A., Ocan, O. (1978) On relationship in the Precambrian migmatite-gneiss of Nigeria. Journal of Mining and Geology, 15: 23-30.

[4] Abiola, O., Enikanselu, P.A., Oladapo, M.I. (2009). Groundwater Potential and Aquifer Protective Capacity of Overburden Units in Osun State University, Southwestern Nigeria. International Journal of Physical Sciences, 4(3): 120-132.

[5] Badmus, B.S., Olatinsu, O.B. (2012). Geophysical characterization of basement rocks and groundwater potentials using electrical sounding data from Odeda Quarry Site, South-western, Nigeria. Asian Journal of Earth Sciences, 5:79-87. https://doi.org/10.3923/ajes.2012.79.87

[6] Shemang, E.N. (1993). Groundwater potentials of Kubami River Basin, Zaria, Nigeria, from D.C. Resistivity study. Water Resources, (1 and 2): 36-41.

[7] Olo Ayuk, M.A., Adelusi, A.O., Adiat, N. (2013). Evaluation of groundwater potential and aquifer protective capacity assessment at Tutugbua-Olugboyega area, off Ondo road, Akure Southwestern Nigeria. International Journal of Physical Sciences, 8(1): 37-50, 9. https://doi.org/10.5897/IJPS09.299

[8] Bala, A.E, Ike, E.C. (2001). The aquifer of the crystalline rocks in Gusau area, Northwestern Nigeria. Journal of Mining and Geology, 37(2): 177-184

[9] Oladapo, M.I, Akintorinwa, O.J. (2007). Hydrogeophysical Study of Ogbese Southwestern, Nigeria. Global Journal of Pure and Applied Sciences, 13(1): 55-61. https://doi.org/10.4314/gjpas.v13i1.16669

[10] Clark, L. (1985). Groundwater abstraction from basement complex areas of Africa. Quarterly Journal of Engineering Geology and Hydrogeology, 18: 25-34. https://doi.org/10.1144/GSL.QJEG.1985.018.01.05 